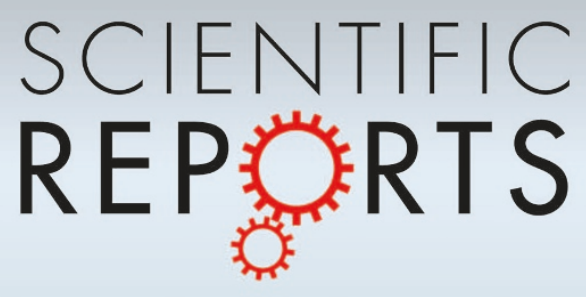

OPEN

SUBJECT AREAS:

CONSERVATION

FORESTRY

ENVIRONMENTAL SCIENCES

SUSTAINABILITY

Received

15 January 2014

Accepted

31 March 2014

Published

17 April 2014

Correspondence and requests for materials should be addressed to

M.F. (matt.finer@ gmail.com)

\section{Logging Concessions Enable Illegal Logging Crisis in the Peruvian Amazon}

\author{
Matt Finer ${ }^{1,2}$, Clinton N. Jenkins ${ }^{3,4}$, Melissa A. Blue Sky ${ }^{1} \&$ Justin Pine ${ }^{5}$
}

\begin{abstract}
${ }^{1}$ Center for International Environmental Law, Washington, DC, USA, ${ }^{2}$ Amazon Conservation Association, Washington, DC, USA, ${ }^{3}$ Instituto de Pesquisas Ecológicas, Nazaré Paulista, SP, Brazil, ${ }^{4}$ Department of Biological Sciences, North Carolina State University, Raleigh, NC, USA, ${ }^{5}$ Northern Arizona University, Flagstaff, AZ, USA.
\end{abstract}

The Peruvian Amazon is an important arena in global efforts to promote sustainable logging in the tropics. Despite recent efforts to achieve sustainability, such as provisions in the US-Peru Trade Promotion Agreement, illegal logging continues to plague the region. We present evidence that Peru's legal logging concession system is enabling the widespread illegal logging via the regulatory documents designed to ensure sustainable logging. Analyzing official government data, we found that $68.3 \%$ of all concessions supervised by authorities were suspected of major violations. Of the 609 total concessions, nearly $30 \%$ have been cancelled for violations and we expect this percentage to increase as investigations continue. Moreover, the nature of the violations indicate that the permits associated with legal concessions are used to harvest trees in unauthorized areas, thus threatening all forested areas. Many of the violations pertain to the illegal extraction of CITES-listed timber species outside authorized areas. These findings highlight the need for additional reforms.

ustainable logging in the tropics is a commonly cited goal at the international level, but has been difficult to achieve on the ground in all three major tropical forest regions $s^{1,2}$. In particular, illegal logging is widespread throughout the tropics, and corruption is a commonly cited cause ${ }^{3-8}$. However, comprehensive and quantitative analyses of precisely how existing legal frameworks facilitate this illegal logging are rare. Here, we focus on the Peruvian Amazon and analyze official information to better understand both the geographic scale and documented legal violations related to illegal logging.

The Peruvian Amazon is an important arena in efforts to promote sustainable commercial logging due to its large forested area, high biodiversity, sizable concentrations of desired hardwoods (such as mahogany and cedar), and widespread problems with illegal logging ${ }^{9-11}$. The cornerstone of Peru's forest policy since 2000 has been the Forest and Wildlife Law No. 27308, whose central objective is to establish a framework for the "sustainable use and conservation of forest resources" (Article 1) ${ }^{12}$. Subsequently, the US-Peru Trade Promotion Agreement (TPA), which entered into force in February 2009, contained an important annex aimed at strengthening Peru's forest sector governance and sustainable management of forest resources ${ }^{13}$.

Despite these efforts, it is increasingly clear that sustainable forestry has yet to be attained and illegal logging continues to plague the Peruvian Amazon ${ }^{14-17}$. Although the general failings of the Peruvian logging system have been known for years, we present an up to date, comprehensive analysis to identify the geographic scale and legal violations related to the problem. We focus on the technical aspects driving the overall illegal logging crisis and do not address the important associated social issues. For more information on issues related to indigenous communities, indigenous peoples living in voluntary isolation, labor and human rights violations, and corruption, see the following works ${ }^{14,18-20}$.

We present evidence that Peru's legal logging concession system, established in the 2000 Forestry Law and later reinforced by the US-Peru TPA, is enabling widespread illegal logging. Our analysis indicates that logging is not contained to delimited concessions and continues to threaten all forested areas, including protected areas and indigenous territories. Moreover, this illegal timber extraction takes place using the very regulatory documents designed to ensure sustainable logging.

The 2000 Forestry Law introduced a new regime for controlled access to Peru's forest resources via a system of concessions, permits, and authorizations ${ }^{16}$. We focused on the concessions, which are formal contracts valid for up to forty years between the government and the concessionaire for specific tracts of public land between 4,000 and 50,000 $\mathrm{ha}^{21}$. Permits and authorizations are typically for smaller forest units on private and indigenous lands. As of September 2013, the Peruvian government had created 609 logging concessions, all in the Amazon watershed. 
The 2000 Forestry Law also introduced a seemingly comprehensive regulatory framework designed to ensure that logged trees come from concessions and not surrounding unauthorized or sensitive areas. This framework features a General Forest Management Plan (hereafter PGMF for the Spanish acronym), whereby the concessionaire projects what trees they expect to extract over the next five years, and a more detailed Annual Operating Plan (hereafter POA for the Spanish acronym) for each year of operation ${ }^{14}$. Each concession is sub-divided into smaller parcels, generally from 400 to 500 ha, only one of which can be logged each year. The POA includes detailed information for each individual tree to be extracted in that year's particular parcel, including species, estimated harvest volume of sawn timber, and GPS coordinates ${ }^{14}$.

Based on the information in the approved POA, a concessionaire may remove timber from a concession. The transported material must be accompanied by a document known as a Forest Transport Permit (hereafter GTF for the Spanish acronym). A GTF includes information regarding the species, volume, and place of origin of the transported material. These GTFs are used to create a Balance of Extraction, which works as a type of debit system for monitoring the volume of each species extracted that year from each parcel ${ }^{14}$.

The 2000 Forestry Law also provided for creation of the supervisory body OSINFOR (Created as "Organismo Supervisor de los Recursos Forestales Maderables" but currently known as "Organismo de Supervisión de los Recursos Forestales y de Fauna Silvestre"). Their central role is to carry out post-harvest field inspections, known as supervisions, to ensure that the concessionaire complied with both the annual operating plan and national regulations ${ }^{14}$. However, OSINFOR was housed under the forest authority at the time (INRENA - Instituto Nacional de Recursos Naturales) and financed by timber harvest revenues, creating a structure plagued with perverse incentives and contradictory institutional pressures ${ }^{14}$.

In 2006, under the framework of the US - Peru TPA's Forestry Annex, Peru committed to a number of important actions, including to: deter the falsification of information on key documents (such as PGMF, POA, and GTF); deter timber harvesting outside authorized areas; and improve the management of forest concessions ${ }^{13}$. In addition, Peru committed to implement policies to monitor CITES (Convention on International Trade in Endangered Species of Wild Fauna and Flora) listed species including big-leaf mahogany (Swietenia macrophylla) and cedar (Cedrela fissilis and C. odorata). Should a POA contain one of these species, a forest authority must physically inspect the concession to verify its presence prior to cutting to ensure that the eventually logged trees are indeed from the concession in question. Another key component of the US-Peru TPA called for the establishment of OSINFOR as an independent agency. In 2008, OSINFOR did gain greater independence when it was placed within the Presidency of the Council of Ministers ${ }^{22}$.

During the supervision, OSINFOR verifies the existence and measurements of a sample of trees at the GPS coordinates specified in the POA. For example, if the concessionaire harvested a tree, the inspector should find evidence, such as a freshly cut stump, at that location. If OSINFOR detects violations, they may initiate an investigation through an administrative procedure known as "PAU" (Procedimiento Administrativo Único ${ }^{23}$. If the violations are confirmed, OSINFOR issues a sanction. A sanction may be a monetary fine, and/ or if violations are sufficiently serious, cancelation of the concession.

Despite advances with OSINFOR, the widespread reports of continued illegal logging across the Peruvian Amazon suggest that the provisions to promote sustainable logging established in the 2000 Forestry Law and the 2009 US-Peru TPA are not working. To investigate the root of the problem, we used OSINFOR data to 1) document how many of the logging concessions have been cancelled for severe violations, and 2) examine, with a focus on the Department of Loreto in the northern Peruvian Amazon, whether the nature of the violations indicate that the legal logging concessions are enabling the illegal logging. Loreto makes an ideal focal area because it is by far the largest department in Peru $\left(\sim 369,000 \mathrm{~km}^{2}\right)$, is home to over $40 \%$ (254) of the logging concessions, and is the top producer of raw $\log { }^{24-26}$.

\section{Results and discussion}

We grouped the logging concessions into four categories based on whether or not they have been supervised and the results of those supervisions (Figure 1, Table 1). Between January 2005 and September 2013, OSINFOR had conducted over 500 supervisions in 388 of the 609 logging concessions (63.7\%). The majority of these supervisions took place after OSINFOR gained greater independence in 2009. Of these supervised concessions, OSINFOR cancelled 181 (46.7\%) due to confirmed major violations (Cancelled/Caducado). OSINFOR was investigating an additional 84 concessions (21.6\%) for suspected violations (Investigation/PAU). Together, this means that $68.3 \%$ of all supervised concessions are either cancelled or under investigation for major violations. In contrast, 123 concessions (31.7\%) were still active (Active - Supervised/Vigente) following the OSINFOR supervision process, although a considerable number of these were fined for lesser violations.

In sum, $43.5 \%$ of the 609 logging concessions are either cancelled or under investigation for major violations. In contrast, OSINFOR has cleared just $20.2 \%$ for lesser or no violations. We expect the number of cancelled concessions to increase, as OSINFOR had not yet supervised 221 concessions (36.3\%) as of August 29, 2013 (Active - not Supervised/Vigente). For example, in the 20 months between November 2011 and August 2013, the number of cancelled concessions in Loreto increased 300\% (from 14 to 56).

Our more detailed analysis of Loreto revealed a major problem with the logging concession system (Tables 2 and 3). Of the 254 concessions in Loreto, OSINFOR had supervised 140 (55.1\%) as of August 29, 2013. Of these, we obtained and reviewed the resolutions for 102 concessions. These resolutions contain information pertaining to infractions and criteria for canceling concessions established in the 2000 Forestry Law (Article 18) and the implementing regulation (Articles 91 and 363).

The majority of logging concessions are enabling illegal logging outside the approved concession area. OSINFOR cited over $55 \%$ of the supervised concessions with timber extraction outside of the concession limits (Articles 18c and 91A-e). Moreover, OSINFOR cited $68.6 \%$ of the supervised concessions with using the concession to facilitate the extraction or transport of illegal timber (Article $363 \mathrm{w})$.

Furthermore, our results indicate that the pre-harvest regulatory framework, particularly in regards to CITES-listed cedar species, is also clearly not working. OSINFOR cited nearly $80 \%$ of the supervised concessions with non-compliance of the PGMF or POA (Articles 18a, 91A-a and 91A-b). Notably, they cited the submission of false or incomplete information in $63.7 \%$ of the supervised concessions (Article 363t) and did not even find indications of a preharvest census in $26.5 \%$ of the supervised concessions. One of the most commonly cited problems was not finding the stumps of the supposedly harvested trees at the coordinates stated in the POA. Another common problem was that the extracted trees documented in the Balance of Extraction were not actually extracted from the indicated parcel. In some cases, inspectors even found harvestable trees still standing at the coordinates indicated in the POA.

Many of the violations pertain to the illegal extraction of CITESlisted cedar species, cited in $57.8 \%$ of the supervised concessions. We note that all of these violations were discovered in inspections done during 2009 or later-after entry into force of the US-Peru TPA. In nearly all of these cases (56.9\%), OSINFOR did not find the stumps of the supposedly harvested trees at the coordinates stated in the POA. Similarly, in $52.9 \%$ of the supervised concessions, the extracted cedar documented in the Balance of Extraction was not actually extracted 


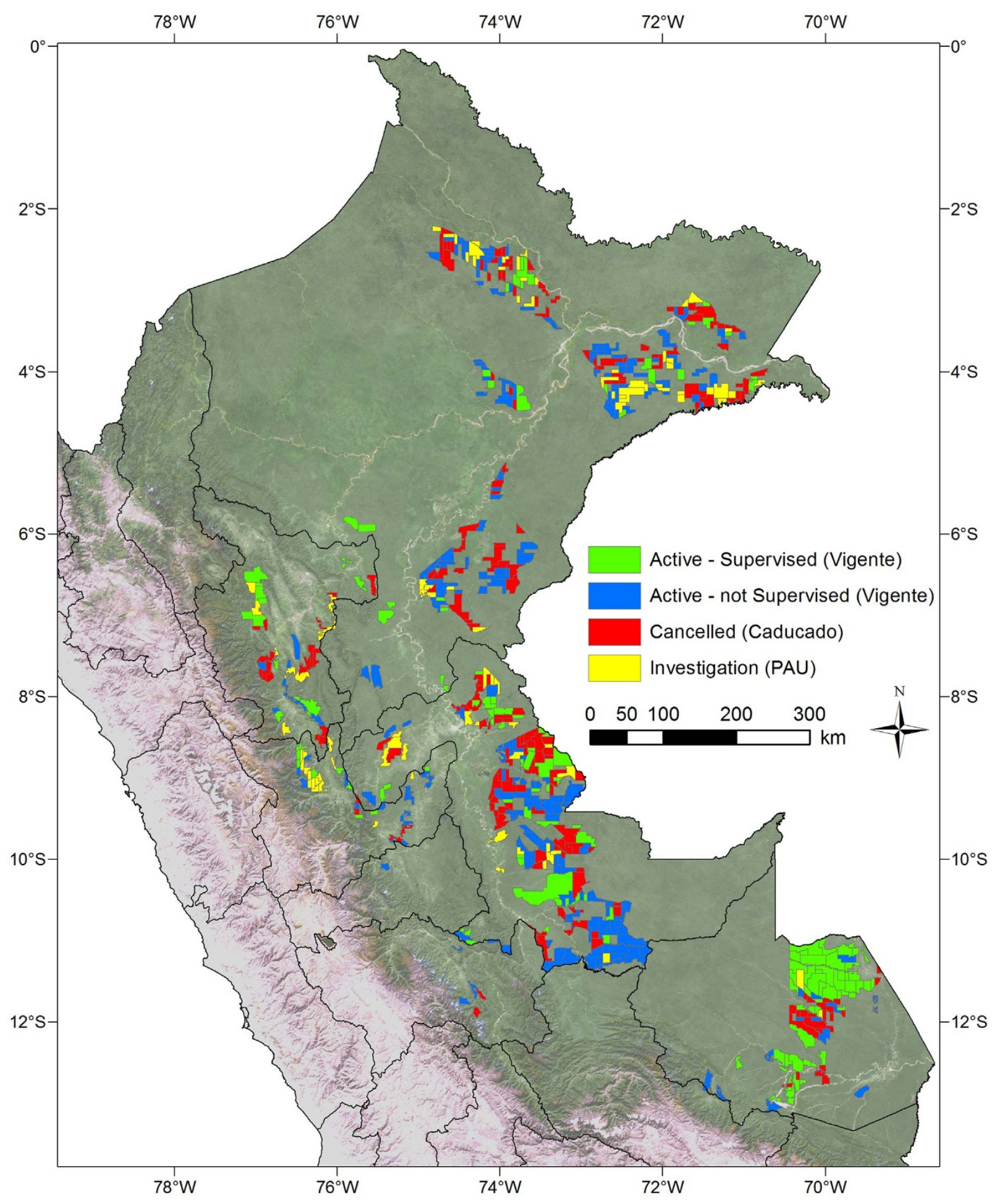

Figure $1 \mid$ Status of logging concessions in the Peruvian Amazon. See text for category explanations. Figure was made with ArcGIS 10.1.

\begin{tabular}{|lccc|}
\hline Table 1 | Status of logging concessions in the Peruvian Amazon & & \\
Status & Number of Concessions & \% of Supervised & \% of Total Concessions \\
\hline Cancelled (Caducado) & 181 & $46.7 \%$ & $29.7 \%$ \\
Investigation (PAU) & 84 & $21.6 \%$ & $13.8 \%$ \\
Active - Supervised (Vigente) & 123 & $31.7 \%$ & $20.2 \%$ \\
Total Supervised by OSINFOR & $\mathbf{3 8 8}$ & $63.7 \%$ \\
Active - not Supervised (Vigente) & 221 & $36.3 \%$ \\
Total Logging Concessions & $\mathbf{6 0 9}$ & \\
\hline
\end{tabular}


Table 2 | Cited violations in logging concessions supervised by OSINFOR pertaining to the Forest and Wildlife Law No. 27308 and its implementing regulation. Percentages over $50 \%$ are in bold

\begin{tabular}{|c|c|c|}
\hline \multicolumn{3}{|c|}{ Forest and Wildlife Law No. 27308} \\
\hline Article 18 & Grounds for revoking harvesting rights & \\
\hline a & Failure to comply with the General Forest Management Plan & 79.4\% \\
\hline b & Failure to pay for harvesting rights & $25.5 \%$ \\
\hline c & Timber extraction outside of the concession limits & $\mathbf{5 7 . 8} \%$ \\
\hline d & Promote timber extraction through a third party & $11.8 \%$ \\
\hline \multicolumn{3}{|c|}{ Regulations of Forest and Wildlife Law No. 27308} \\
\hline Article 91A & Grounds for cancellation of a concession & \\
\hline a & Failure to present management plans within the established timeframe & $15.7 \%$ \\
\hline b & Failure to implement management plans & $63.7 \%$ \\
\hline$d$ & Failure to pay harvesting rights within the established timeframe & $19.6 \%$ \\
\hline e & Timber extraction outside of the concession limits & $55.9 \%$ \\
\hline$f$ & Promote illegal timber extraction through a third party & $16.7 \%$ \\
\hline h & Waiver of concession rights by the concessionaire & $10.8 \%$ \\
\hline Article 363 & Forestry Infractions & \\
\hline i & Unauthorized timber extraction or extraction outside authorized zone & 79.4\% \\
\hline k & Cutting seed or regeneration trees & $14.7 \%$ \\
\hline | & Failure to comply with established harvesting methods & $61.8 \%$ \\
\hline $\mathrm{n}$ & Timber extraction exceeding authorized volumes & $2.9 \%$ \\
\hline q & Acquisition, transformation, or marketing of illegally extracted timber & $3.9 \%$ \\
\hline$\dagger$ & Submission of false or incomplete information & $63.7 \%$ \\
\hline w & Use concession to facilitate extraction, transport, or marketing of illegally extracted timber & $71.6 \%$ \\
\hline
\end{tabular}

from the indicated parcel. Interestingly, in $23.5 \%$ of the supervised concessions, harvestable cedar trees were still standing at the coordinates indicated in the POA. It is worth noting that although the illegal extraction of mahogany does not seem to be a major problem in Loreto (OSINFOR cited the illegal extraction of mahogany in just $5.9 \%$ of the supervised concessions), this may be a bigger issue in southern Peru where remaining mahogany densities are higher ${ }^{10,27}$. Of the six concessions with mahogany violations, four were documented after 2009.

In summary, we find that the following scenario is common: 1) concessionaire indicates the presence of abundant timber, particular cedar, in the POA, 2) concessionaire later claims the authorized logging took place, but instead used the permits to facilitate extraction and transit of timber outside the concession area, 3) OSINFOR eventually inspects the concession area and finds that the information in the POA was false because there are no stumps of the supposedly harvested trees at the given coordinates, or 4) in a surprising number of cases, OSINFOR finds that the POA was accurate, but the supposedly harvested trees are still standing, indicating that the concessionaire used the permits for timber harvested elsewhere.

These findings lead us to conclude that the regulatory documents designed to promote sustainable logging are instead enabling illegal logging. Specifically, logging permits based on falsified annual plans are widely used to harvest trees in unauthorized areas. As a result, much of the timber coming out of the Peruvian Amazon is sourced outside of authorized concession areas. Thus, we argue that the problem is a combination of a lack of oversight and enforcement prior to OSINFOR inspections, and fundamental shortcomings of existing law.

At the heart of the problem is that authorities only check the regulatory documents in transport or at port arrival, well after the timber has left the forest. Likewise, the main field inspection also occurs post-harvest. This means that in practice the transport permits (GTFs) are not linked to the concession area in question. Instead, they become a tradable item and enable loggers to launder timber extracted outside of authorized areas ${ }^{16}$. Once timber in transit has a GTF, it is very difficult for authorities to identify the original source of the timber.

Fieldwork and analysis of satellite imagery supports these findings. Sears and Pinedo-Vasquez ${ }^{16}$ found regular inconsistencies between the location of the authorized logging areas and the actual origin of the raw logs through interviews with loggers arriving to a port in southern Loreto. Oliveira et al., using the Carnegie Landsat Analysis System (CLAS), found that both forest disturbance and deforestation rates were substantially higher outside concessions than inside them in the northern and central Peruvian Amazon ${ }^{11}$.

Until there is a significantly improved regulatory system in place, consisting of both improved enforcement and legal reforms, it will remain difficult to control the Peruvian forestry sector and effectively restrict logging to authorized areas ${ }^{16}$. Under the current system, the

Table 3 | Additional cited violations in logging concessions supervised by OSINFOR. Percentages over $50 \%$ are in bold

Violation

Illegal extraction of cedar

Illegal extraction of mahogany

Cedar tree or stump not found within $50 \mathrm{~m}$ of the GPS coordinates in the POA

Mahogany tree or stump not found within $50 \mathrm{~m}$ of the GPS coordinates in the POA

Other species tree or stump not found within $50 \mathrm{~m}$ of the GPS coordinates in the POA

Seed tree not found within $50 \mathrm{~m}$ of the GPS coordinates in the POA

Volume (cedar) documented in Balance of Extraction not from concession unit

Volume (non-cedar) documented in Balance of Extraction not from concession unit

Authorized timber (cedar) in the POA left standing

Authorized timber (non-cedar) in the POA left standing

No indications of a census being performed

Tree marked as cedar in the POA found to be another species
Percent

$\mathbf{5 7 . 8} \%$

$5.9 \%$

$\mathbf{5 6 . 9 \%}$

$5.9 \%$

$41.2 \%$

$37.3 \%$

$\mathbf{5 2 . 9} \%$

$40.2 \%$

$23.5 \%$

$18.6 \%$

$26.5 \%$

$6.9 \%$ 
two main ways to identify illegal logging-discovery of timber in transit without GTFs or post-harvest OSINFOR inspection-come far too late to be effective ${ }^{15}$. Until the legal system shifts the focus away from transit documents and towards verifying extraction of wood at the source and the subsequent chain of custody, widespread illegal logging will likely persist.

In the larger context, reconciling forest conservation and logging cannot be attained until timber extraction is contained to authorized concessions and not rampant throughout the landscape. This reconciliation centers on the prospect of combining protected areas with forest logging concessions to better conserve forest across a larger area than possible by protected areas alone ${ }^{28,29}$. This concept assumes that selectively logged concessions can maintain forest cover across the landscape better than other land uses, such as agriculture. However, if the logging concessions are in fact facilitating illegal logging within protected areas and indigenous territories, this goal cannot be met.

Finally, we note that a new Forestry law was passed in July $2011^{30}$, but as of the time of writing it had not yet gone into effect due to delays in the adoption of the implementing regulations (draft regulations were released in September 2013). However, the new 2011 Forestry Law maintains the same general logging concession system that is the subject of this study.

\section{Methods}

Logging concession spatial data are from the Agriculture Ministry Forest Authority (Dirección General Forestal y de Fauna Silvestre del Ministerio de Agricultura), including for both major types of logging concessions ("Otorgados por Concurso Publico" and "Adecuación de Contrato"). These data included information for 609 logging concessions in the Peruvian Amazon. Data on the status of logging concessions are from OSINFOR, the government entity that carries out the post-harvest supervisions. These data reflected conditions as of August 29, 2013.

We summarized the OSINFOR classifications as follows: "Caducado" and "Sancionado y Caducado" classified as Cancelled (Caducado); "En PAU” classified as Investigation (PAU); "Archivar PAU", "Sancionado" and "Archivado por no encontrar indicios de infracciones a la Legislación Forestal" classified as ActiveSupervised (Vigente); and "En Evaluación Legal" classified as Active-not Supervised or Decision Pending (Vigente). We assumed that concessions not included in OSINFOR data have not yet been supervised and therefore were classified as Activenot Supervised or Decision Pending (Vigente).

Concessions labeled by OSINFOR as "Caducado" represent cases where they documented major violations and were subsequently cancelled (thus labeled Cancelled in our system). Concessions labeled by OSINFOR as "En PAU" represent cases where they suspected major violations and are currently investigating (thus labeled Investigation in our system).

Concessions labeled in our system as Active-Supervised encompass a range of supervision outcomes: 1) concessions where OSINFOR performed a supervision and found no infractions ("Archivado por no encontrar indicios de infracciones a la Legislación Forestal y de Fauna Silvestre"), 2) concessions where OSINFOR suspected violations, but were later cleared ("Archivar PAU"), and 3) concessions where OSINFOR documented violations, but were only fined ("Sancionado").

Concessions labeled in our system as Active-not Supervised or Decision Pending encompass: 1) concessions labeled by OSINFOR as "En Evaluación Legal," which represents concessions that have been recently supervised but it is still unknown if OSINFOR suspects violations, and 2) concessions that did not appear in the OSINFOR data.

For the analysis of documented violations in Loreto, we obtained from OSINFOR the resolutions (Resolución Directoral) emitted following their evaluation of the postharvest supervision. Of the 140 supervised concessions in Loreto, we obtained the resolutions for 102. All but five of these resolutions are from after 2009, the period when OSINFOR gained greater independence from logging interests. The unobtained resolutions were for newly supervised concessions and were emitted after we closed our data-collection process.

We evaluated each resolution for the following four classes of data: 1) Article 18 of the Forest and Wildlife Law No. 27308 (this article details the grounds for revoking harvesting rights), 2) Article 91A from the implementing regulations of the Forest and Wildlife Law No. 27308 (this article details the grounds for cancellation of a concession), 3) Article 363 from the implementing regulations of the Forest and Wildlife Law No. 27308 (this article details the documented forestry infractions), and 4) additional items pertaining to CITES species or other important violations that were not captured in the three Articles noted above.

1. Zimmerman, B. L. \& Kormos, C. F. Prospects for sustainable logging in tropical forests. Bioscience 62, 479-487 (2012).
2. Smith, J., Colan, V., Sabogal, C. \& Snook, L. Why policy reforms fail to improve logging practices: The role of governance and norms in Peru. For. Policy Econ. 8, 458-469 (2006).

3. Teye, J. K. Corruption and illegal logging in Ghana. Int. Dev. Plan. Rev. 35, 1-19 (2013).

4. Ute, S. \& Elwert, G. Combating corruption and illegal logging in Bénin, West Africa. Sustain. For. 19, 239-261 (2008).

5. Palmer, C. E. The extent and causes of illegal logging: an analysis of a major cause of tropical deforestation in Indonesia. (Centre for Social and Economic Research on the Global Environment, 2001).

6. Sikora, T. \& Xuan To, P. Illegal logging in Vietnam: Lam Tac (forest hijackers) in practice and talk. Soc. Nat. Resour. 24, 688-701 (2011).

7. Cerutti, P. O., Tacconi, L., Lescuyer, G. \& Nasi, R. Cameroon's hidden harvest: commercial chainsaw logging, corruption, and livelihoods. Soc. Nat. Resour. 26, 539-553 (2013).

8. Smith, J., Obidzinski, K. Subarudi \& Suramenggala, I. Illegal logging, collusive corruption and fragmented governments in Kalimantan, Indonesia. Int. For. Rev. 5, 293-302 (2003).

9. Bass, M. S. et al. Global conservation significance of Ecuador's Yasuní National Park. PLoS One 5, e8767 (2010).

10. Kometter, R. F. et al. Impacts of unsustainable mahogany logging in Bolivia and Peru. Ecol. Soc. 9, (2004).

11. Oliveira, P. J. C. et al. Land-use allocation protects the Peruvian Amazon. Science 317, 1233-6 (2007).

12. República del Perú. Ley Forestal y de Fauna Silvestre. Ley No. 27308 (2000).

13. United States - Peru Trade Promotion Agreement. (2006).

14. Urrunaga, J., Johnson, A., Orbegozo, I. D. \& Mulligan, F. The Laundering Machine. (Environmental Investigation Agency, 2012).

15. Finer, M., Blue Sky, M. \& Jenkins, C. N. Sector forestal en Loreto, Perú: estado actual e implicancias ecológicas y sociales. In Rev. Latinoam. Derecho y Políticas Ambient. 151-184 (DAR, 2012).

16. Sears, R. R. \& Pinedo-Vasquez, M. Forest policy reform and the organization of logging in Peruvian Amazonia. Dev. Change 42, 609-631 (2011).

17. Neuman, W. \& Zarate, A. Corruption in Peru aids cutting of rain forest. New York Times (2013) at <http://www.nytimes.com/2013/10/19/world/americas/ corruption-in-peru-aids-cutting-of-rain-forest.html?_r=0 $>$ Date of access: 26/ $03 / 2014$.

18. Youatt, A. \& Cmar, T. The fight for red gold: ending illegal mahogany trade from Peru. Nat. Resour. Environ. 23, 19-23 (2009).

19. Garland, E. B. \& Silva-Santisteban, A. B. El trabajo forzoso en la extraccion de madera en la Amazonía Peruana. 43 (ILO, 2005).

20. Napolitano, D. A. Towards understanding the health vulnerability of Indigenous Peoples Living in Voluntary Isolation in the Amazon rainforest: experiences from the Kugapakori Nahua Reserve, Peru. Ecohealth 4, 515-531 (2007).

21. Dirección General Forestal y de Fauna Silvestre. Spatial data of logging concessions. (Ministerio de Agricultura, 2010).

22. República del Perú. Ley que Crea el Organismo de Supervision de los Recursos Naturales y de Fauna Silvestre. Decreto Legis. No. 1085 (2008).

23. República del Perú. Reglamento de Procedimiento Administrativo Unico del OSINFOR. Resoluc. Pres. No. 007-2013-OSINFOR (2013).

24. Dirección General Forestal y de Fauna Silvestre. Peru Forestal en Numeros 2012. 4805 (Ministerio de Agricultura, 2013).

25. Salo, M. \& Toivonen, T. Tropical timber rush in Peruvian Amazonia: spatial allocation of forest concessions in an uninventoried frontier. Environ. Manage. 44, 609-23 (2009).

26. Salo, M., Helle, S. \& Toivonen, T. Allocating logging rights in Peruvian Amazonia--does it matter to be local? PLoS One 6, e19704 (2011).

27. OSINFOR. Modelamiento espacial de nichos ecológicos para la evaluación de presencia de especies forestales maderables en la Amazonía Peruana. (OSINFOR, 2013).

28. Gaveau, D. L. a et al. Reconciling forest conservation and logging in Indonesian Borneo. PLoS One 8, e69887 (2013).

29. Vanclay, J. \& Sheil, D. Can forest conservation and logging be reconciled? The Conversation (2012) at $<\mathrm{http}: / /$ theconversation.com/can-forest-conservationand-logging-be-reconciled-7811 $>$ Date of access: 26/03/2014.

30. República del Perú. Ley Forestal y de Fauna Silvestre. Ley No. 29763 (2011).

\section{Acknowledgments}

Support for research was provided by the Gordon and Betty Moore Foundation. We thank officials in both the national Peruvian government (OSINFOR and Ministry of Agriculture) and the Forestry Department of the Loreto Regional Government (PRMRFFS) for access to data and comments. We also thank Emily Aguilar for key legal analysis and Julia Urrunaga and Kris Genovese for reviewing manuscript.

\section{Author contributions}

M.F. designed the study and collected data. C.N.J. prepared Figure 1. M.F., C.N.J., M.B.S and J.P. contributed to data analysis and writing of the manuscript. 


\section{Additional information}

Competing financial interests: The authors declare no competing financial interests.

How to cite this article: Finer, M., Jenkins, C.N., Blue Sky, M.A. \& Pine, J. Logging Concessions Enable Illegal Logging Crisis in the Peruvian Amazon. Sci. Rep. 4, 4719; DOI:10.1038/srep04719 (2014). (i) (2) This work is licensed under a Creative Commons Attribution-NonCommercialShareAlike 3.0 Unported License. The images in this article are included in the article's Creative Commons license, unless indicated otherwise in the image credit; if the image is not included under the Creative Commons license, users will need to obtain permission from the license holder in order to reproduce the image. To view a copy of this license, visit http://creativecommons.org/licenses/by-nc-sa/3.0/ 